\title{
INVESTIGATION OF THE MECHANICAL PROPERTIES OF AlSi9Cu3(Fe)/MWCNT NANOCOMPOSITES PREPARED BY HPDC
}

\author{
RAZISKAVA MEHANSKIH LASTNOSTI AISi9Cu3(Fe)/MWCNT \\ NANOKOMPOZITOV, PRIPRAVLJENIH S POSTOPKOM HPDC
}

\author{
Vedrana Špada ${ }^{*}$, Davor Stanić2 , Ivan Brnardic ${ }^{3}$ \\ ${ }^{1}$ METRIS Materials Research Centre of Region of Istria, Zagrebačka 30, 52100 Pula, Croatia \\ ${ }^{2}$ CIMOS, P.P.C. Buzet d.o.o., Most 24, 52420 Buzet, Croatia \\ ${ }^{3}$ University of Zagreb, Faculty of Metallurgy, Aleja narodnih heroja 3, 44000 Sisak, Croatia \\ Prejem rokopisa - received: 2019-01-05; sprejem za objavo - accepted for publication: 2019-03-11
}

doi:10.17222/mit.2019.006

\begin{abstract}
In this research, an often-used high-pressure die-casting (HPDC) AlSi9Cu3(Fe) alloy was chosen as the matrix for an Al-alloy/MWCNT nanocomposite material that could be, in the case of targeted mechanical properties, used for the production of lighter car parts. In the industrial experiment, nanocomposite samples were prepared by a HPDC machine from a base $\mathrm{A} 1 \mathrm{Si} 9 \mathrm{Cu} 3(\mathrm{Fe})$ alloy with three different mass ratios of MWCNTs placed on two different positions inside the casting machine. The structure and thermal stability of the used MWCNTs were visually confirmed by scanning electron microscopy (SEM). The microstructural and metallographic properties were studied using an optical microscope. The mechanical properties (tensile strength, elongation at break and hardness) were investigated using a universal testing machine and a Vickers hardness tester. The experimental results of this research showed that the HPDC-prepared Al-alloy matrix nanocomposite material had significantly changed mechanical properties even with small MWCNT contents. The elongation at break and the tensile strength of the Al-alloy/MWCNT nanocomposite were increased in comparison with the base alloy. The finest microstructure was shown by samples with $0.05 \mathrm{w} / \%$ MWCNTs, which was in correlation with the most significant change in the mechanical properties. Keywords: metal-matrix nanocomposites, $\mathrm{AlSi} 9 \mathrm{Cu} 3(\mathrm{Fe})$ alloy, multi-walled carbon nanotubes (MWCNT), high-pressure die casting (HPDC)
\end{abstract}

Avtorji opisujejo raziskavo izdelave nanokompozitnega materiala s kovinsko osnovo iz zlitine AlSi9Cu3(Fe). Za ojačitveno fazo so uporabili večstenske ogljikove nanocevčice (MWCNT). Za izdelavo kompozita so uporabili visokotlačno brizganje taline v kovinsko orodje oz. deljivi model (HPDC). Ta postopek se najbolj pogosto uporablja za izdelavo lahkih avtomobilskih delov s specifičnimi mehanskimi lastnostmi. Izvajali so industrijske preizkuse na HPDC stroju in pri tem uporabili kovinsko talino AlSi9Cu3(Fe) s tremi različnimi dodatki MWCNT, ki so jih postavili na dve različni mesti v votlini orodja. Strukturno in termično stabilnost uporabljenih MWCNT so potrdili s preiskavo ulitkov pod vrstičnim elektronskim mikroskopom (SEM). Nadalje so izvedli še metalografske preiskave mikrostrukture pod optičnim mikroskopom. Mehanske lastnosti izdelanih materialov, natezno trdnost in raztezek po prelomu, so določili na univerzalnem trgalnem stroju, medtem ko so trdoto določili na standardnem Vickersovem merilniku. Eksperimentalni rezultati te preiskave so pokazali, da so se mehanske lastnosti s postopkom HPDC izdelanega nanokompozita na osnovi Al zlitine znatno spremenile že pri dodatku dokaj malih količin MWCNT. Natezna trdnost in raztezek po prelomu nanokompozita MWCNT/Al-zlitina sta v primerjavi z osnovno Al zlitino narasla. Najbolj drobnozrnato mikrostrukturo so imeli vzorci z dodatkom 0,05 masnih deležev MWCNT, kar se je ujemalo z največjo spremembo mehanskih lastnosti.

Ključne besede: nanokompoziti s kovinsko osnovo, zlitina A1Si9Cu3(Fe), večstenske ogljikove nanocevčice (MWCNT), visokotlačno litje v kovinsko orodje (HPDC)

\section{INTRODUCTION}

Modern material research is more and more dedicated to nanocomposites with polymer and metal matrixes because of their great potential to reduce fuel consumption and carbon dioxide $\left(\mathrm{CO}_{2}\right)$ emissions through lighter parts and a reduction of the total car weight. Recent investigations showed that carbon nanotubes (CNTs), especially multi-walled carbon nanotubes (MWCNTs), could be used as nanofillers for strengthening light metal Al-alloy matrix composites because of their high strength, low mass, great active surface, and good thermo-mechanical stability. Such nanocomposites produced by different industrial procedures showed a

*Corresponding author's e-mail:

vedrana.spada@centarmetris.hr significant improvement in mechanical properties compared to a clean matrix, even with a small mass ratio of added nanotubes.

Modern research in the field of material science and the development of new materials for different uses is devoted to the preparation and characterization of nanocomposites based on polymer and metal matrixes with fillers. ${ }^{1-23}$ Nanofillers have an important role as they improved the chemical, physical and mechanical properties of the nanocomposites, which could then replace commonly used materials for a wide spectra of industrial applications, and also products made from that new material could be reduced in mass and/or thinner, which is an absolute "must" nowadays. One of the most commonly used and investigated nanofillers for composite materials are carbon nanotubes (CNTs) because of their 
high Young's modulus, ${ }^{24}$ which often results in an improvement of the nanocomposite's mechanical properties compared to the pure matrix. For the preparation of metal matrix nanocomposites, multi-walled carbon nanotubes (MWCNTs) were used because of their lower price and industrial scale availability. ${ }^{25-29}$

The literature shows that in modern scientific research, polymer-matrix nanocomposites still dominate over metal-matrix nanocomposites. ${ }^{1-5}$ The reason for this situation in material science can be found in the high melting temperature of metals, which destructively effects CNTs through thermal degradation. Also, there were problems with how to introduce, mix and homogeneously disperse CNTs in a metal matrix, which most certainly had a crucial influence on the final mechanical properties of the produced nanocomposites. The approach in this industrial research was directed to producing light metal-matrix nanocomposite material from an AlSi9Cu3(Fe) alloy with MWCNTs, avoiding the thermal degradation of nanofillers and overcoming the inhomogeneous distribution, followed by better mechanical properties than the matrix itself. Usually, agglomeration caused the formation of micro-aggregates in metal matrix nanocomposites, i.e., "weak spots", resulting in losing the CNT strengthening potential. Some researchers solved these problems with different approaches and methods for nanocomposite preparation. $\mathrm{Li}$ et al. prepared Al-5\% CNT reinforced light metal composites produced by melt stirring. ${ }^{6}$ Uozumi et al. used a squeeze casting fabrication process for carbon nanotube/light metal matrix composites. ${ }^{7}$ Laha et al. produced carbon nanotube reinforced aluminium nanocomposite via plasma and high-velocity oxy-fuel spray forming. ${ }^{8}$ Hao et al. studied the effect of mechanical alloying time and rotation speed on the evolution of CNTs/Al-2024 composite powders. ${ }^{9}$

The aim of this work was to prepare nanocomposite material with a commonly used alloy and an important industrial production method. The high-pressure die casting (HPDC) of $\mathrm{Al}$ car parts production is very often used in the automotive sector, so it became of great importance to successfully prepare Al-alloy nanocomposite material of smaller weight, but better mechanical properties, by using exactly that process and also optimizing it along the way (matrix, nanofillers, and MWCNT content, parameters of casting).

In this industrial experiment, nanocomposites from the AlSi9Cu3(Fe) alloy and multi-walled carbon nanotubes (MWCNTs), with varying mass ratios, were prepared using a high-pressure die casting (HPDC) process. Samples were prepared in two different ways, placing three mass ratios of MWCNTs in two different positions of the HPDC machine. The stability and the influence of MWCNT ( $w / \%$ and position) on the mechanical properties and microstructure of the nanocomposites and base alloy were investigated.

\section{EXPERIMENTAL PART}

The nanofillers were obtained from Chengdu Organic Chem. Co. The characteristics of the industrial MWCNTs were: outside diameter from $5 \mathrm{~nm}$ to $30 \mathrm{~nm}$, purity $>95 \%$ and length from $10 \mu \mathrm{m}$ to $30 \mu \mathrm{m}$. The morphology and diameter of the used MWCNTs were determined by a secondary-electron detector of a field-emission scanning electron microscope (FE-SEM) at different magnifications (Figure 1).

The base alloy AlSi9Cu3(Fe) for car parts production in the Croatian metallurgy and foundry company CIMOS - P.P.C. Buzet Ltd. was used as the metal matrix. The chemical composition of the used alloy in the industrial experiment obtained by optical emission spectrometer with a glow discharged source LECO 500A (OES-GDS) was compared with the required chemical composition according to the norm EN $1706^{29}$ and showed no deviations.

The nanocomposite samples were prepared on a Buhler 42D HPDC machine (Figure 2) at a temperature of $690{ }^{\circ} \mathrm{C}$, a pressure of 800 bar, by 58 s cycles in a specially designed tool containing six samples with different diameters and $0.950 \mathrm{~kg}$ of total weight.
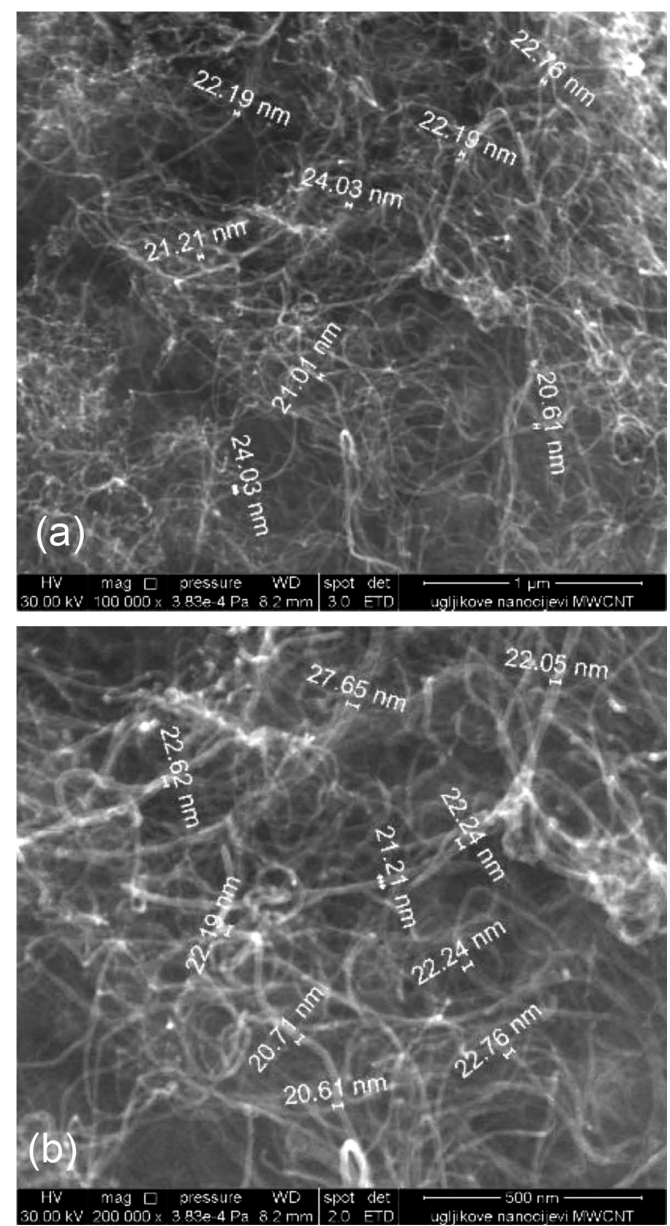

Figure 1: SEM images of MWCNTs with diameter marks at a) $100 \mathrm{kx}$; b) $200 \mathrm{k} \times$ magnification 


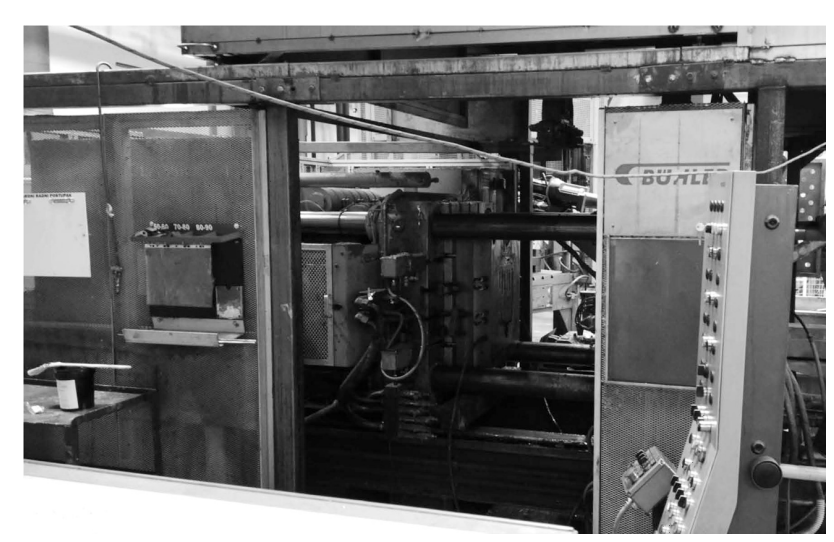

Figure 2: Buhler 42D HPDC machine

The weight of the MWCNTs was measured to prepare the nanocomposites with three different mass ratios of $0.05 \%, 0.1 \%$ and $0.2 \%$ by wrapping the exact mass in commercially available aluminium foil. The nanocomposite samples were prepared in two different ways: firstly by placing the wrapped MWCNTs in the chamber in front of the piston (position 1), and secondly by putting the wrapped MWCNTs at the beginning of the casting cavity (position 2) for exact shape casting formation. Also, reference samples from the base alloy were also cast for comparison. The melted alloy was poured into the chamber and then pushed into the tool by the piston. When the tool opened, the casted samples were cooled in the air, marked and separated for subsequent tests (Figure 3 ).

Every sample was cast five times with an exact procedure and was named as proposed: $\mathrm{R}$ (reference sample - base alloy), C1-0.05, C1-0.1, C1-0.2, C2-0.05, C2-0.1 and C2-0.2 (composite CX-Y, X stands for the

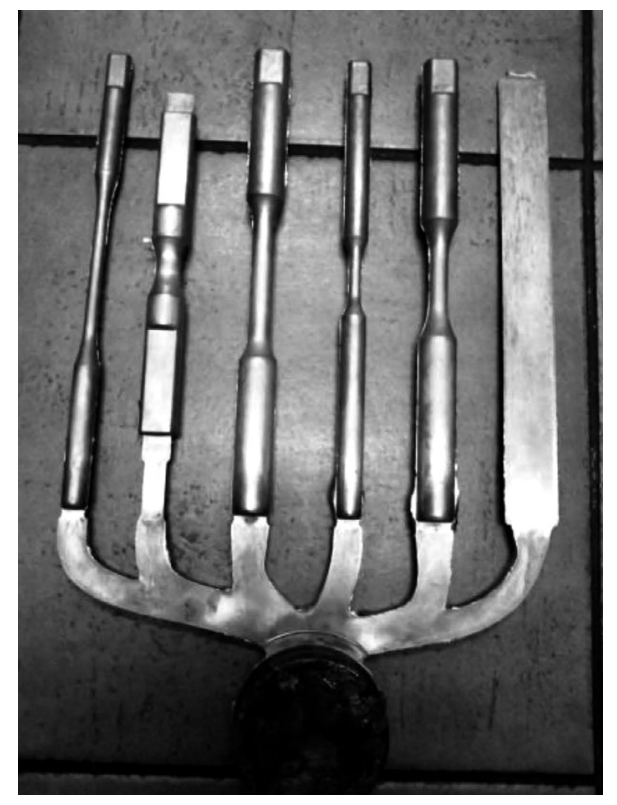

Figure 3: Nanocomposite samples as casted position of the wrapped MWCNTs adding 1 in front of piston, 2 at the beginning of the casting cavity and $\mathrm{Y}$ stand for $w / \%$ of MWCNT).

Mechanical measurements (elongation at break and tensile strength) were performed on a Messphysik BETA 250 testing machine, in the uniaxial tension mode at $25{ }^{\circ} \mathrm{C}$. At least three specimens were tested for the sample, according to the HRN EN ISO 6892-1 standard. The hardness was also tested using a Vickers Duramin 2 device at HV1. The stability and existence of the MWCNTs and the microstructure of the fractured surfaces after the mechanical testing were analyzed with a scanning electron microscope (SEM) in the form of a FEG SEM Quanta 250 FEI microscope. The metallographic investigations were conducted with an optical metallographic microscope BX51 OLYMPUS. Prior to the analysis the samples were metallographically polished and etched with Keller's etchant for 15 s. All the experiments were performed on casted samples with an $6.4 \mathrm{~mm}$ diameter.

\section{RESULTS AND DISCUSSION}

The results of the tensile testing and the hardness of the prepared nanocomposites were summarized in Table 1. Three of the five tested samples were chosen based on deviations.

Table 1: Mechanical properties of the base Al alloy and the Al alloy with different contents of MWCNTs

\begin{tabular}{|c|c|c|c|}
\hline Samples & $\begin{array}{c}\text { Elongation } \\
(\%)\end{array}$ & $\begin{array}{c}\text { Ultimate tensile } \\
\text { strength (MPa) }\end{array}$ & $\begin{array}{c}\text { Hardness } \\
(\mathrm{HV} 1)\end{array}$ \\
\hline $\mathrm{R}$ & $1.93 \pm 0.12$ & $263.2 \pm 2.9$ & $95.1 \pm 2.2$ \\
\hline $\mathrm{C} 1-0.05$ & $2.50 \pm 0.16$ & $274.7 \pm 2.9$ & $93.3 \pm 3.1$ \\
\hline $\mathrm{C} 1-0.1$ & $2.24 \pm 0.20$ & $262.1 \pm 3.7$ & $89.0 \pm 4.8$ \\
\hline $\mathrm{C} 1-0.2$ & $2.28 \pm 0.51$ & $271.9 \pm 4.8$ & $88.5 \pm 3.4$ \\
\hline $\mathrm{C} 2-0.05$ & $2.36 \pm 0.16$ & $273.6 \pm 3.8$ & $89.1 \pm 2.0$ \\
\hline $\mathrm{C} 2-0.1$ & $2.46 \pm 0.15$ & $273.1 \pm 10.9$ & $88.8 \pm 4.1$ \\
\hline $\mathrm{C} 2-0.2$ & $2.57 \pm 0.25$ & $251.4 \pm 7.0$ & $94.3 \pm 5.9$ \\
\hline
\end{tabular}

The nanocomposite samples prepared with $0.05 \mathrm{w} / \%$ of MWCNTs, placing them at position 1 (in front of the piston) in the HPDC machine, showed the best results regarding improving the mechanical properties of the base alloy: breaking elongation by $\approx 30 \%$ and tensile strength by $\approx 4.4 \%$.

The results for the nanocomposites prepared by adding MWCNT at the position 2 in the HPDC machine (C2) showed a larger discrepancy. The hardness was slightly different in the prepared nanocomposites compared to the base alloy.

Furthermore, some samples prepared at position 2 showed micro- and macro-agglomerates of MWCNTs on the fracture surface, which can be correlated to the short period for the melting of the wrapped foil with the hot base alloy, resulting in a non-homogenous distribution, which is in correlation with a larger discrepancy of the mechanical results that can be seen in Table 1. 

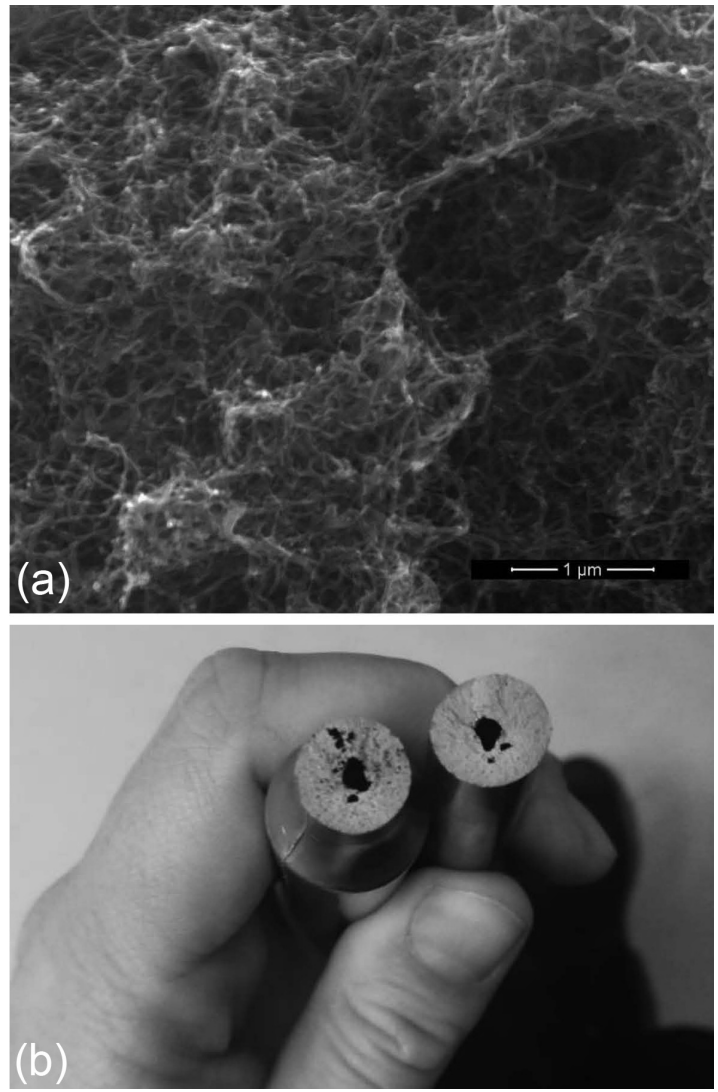

Figure 4: a) SEM image of MWCNTs agglomerated in the C2-0.1 sample, b) photograph of easily visible agglomerate in the mechanically poor C2-0.2 sample

Figure 4 shows the micro (C2-0.1-SEM image) and macro (C2-0.2-photo image) agglomerates in the samples achieved using position 2, which visually explained the poorer mechanical results of the position 2 prepared nanocomposites shown in Table 1.

Thermal degradation of the MWCNTs did not occur in all the prepared AlSi9Cu3(Fe)/MWCNT nanocomposites, which was confirmed by the SEM analysis (Figure 4a). Therefore, the HPDC method for introducing the MWCNT in the metal matrix can be used and the MWCNT are well-chosen nanofillers for HPDC. In addition, the low discrepancy of the results of the mechanical properties shown in Table 1 could mean the homogenous distribution of the MWCNTs in the metal matrix at position 1 for $0.05 \mathrm{w} / \%$ (best mechanical results) is also in correlation with the SEM secondaryelectron detector images of the fracture surface of the C1-0.05 sample in Figures 5a and 5b.

The influence of the MWCNTs on the microstructure of the base Al-alloy was examined under an optical microscope. Figure 6 shows the microstructure of the a) base alloy and b-e) nanocomposite samples with 0.05 $w / \%$ and $0.1 w / \%$ of added MWCNTs in positions 1 and 2. The samples with $0.2 \mathrm{w} / \%$ were obviously inhomogeneous and also without an improvement of the mechanical properties, so they were not metallographically
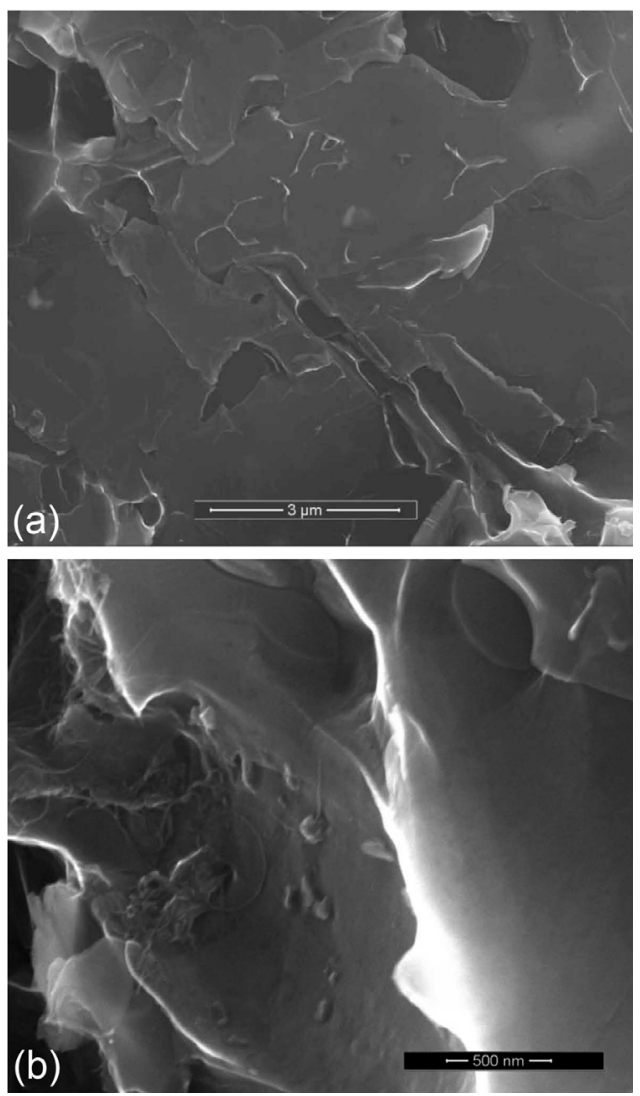

Figure 5: SEM images of sample C1 - 0.05 fracture surface (Al-alloy and MWCNT) showing MWCNTs at a magnification of: a) $30 \mathrm{k} \times$, b) $120 \mathrm{k} \times$

investigated. As can be seen, the microstructure, as expected, changed under the influence of the MWCNTs and the prepared Al-nanocomposites had a finer-grained structure of the primary Al grains than the base alloy, which is in correlation with the better mechanical properties. ${ }^{19-21}$ The finest microstructure of the primary $\mathrm{Al}$ grains is, as expected, found in the 0.05 position 1 samples (Figure 6b), where the $\mathrm{Al}$ grains are smaller than the base alloy and the grain boundaries are fine distributed and clear. Also observed is the correlation with the improvement of the mechanical properties. Other nanocomposites, even position $1(\mathrm{w}=0.01 \%)$ (Figure 6d), showed some black areas on the grain boundaries and nevertheless presented MWCNTs between the finer $\mathrm{Al}$ grains than in the base alloy.

Regarding all the results, position 1 with 0.05 w/\% MWCNT content was the best for the preparation of homogenous Al-alloy/MWCNT nanocomposite samples with HPDC. Such properties could result in thinner and smaller dimensions of different car parts that could reduce the total car weight, the consumption of raw materials and energy in the production process. Success in this research means a great step forward in the development of nanocomposite materials for a wide spectrum of applications and specifically follows trends of more and more strict standards in the automotive sector, along 


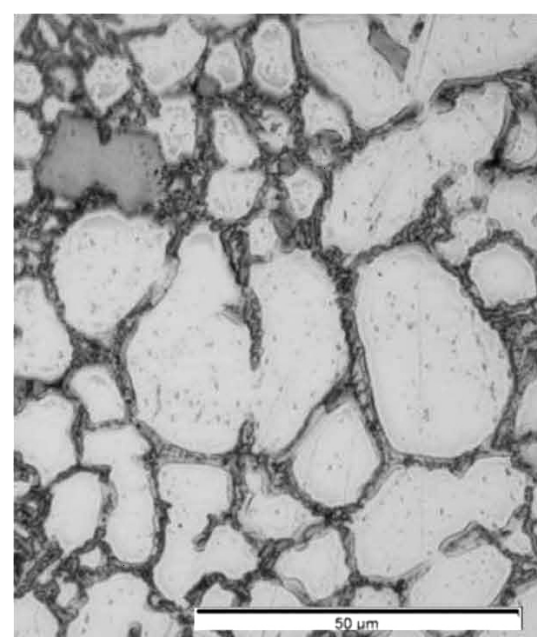

a) $\mathbf{R 1}$

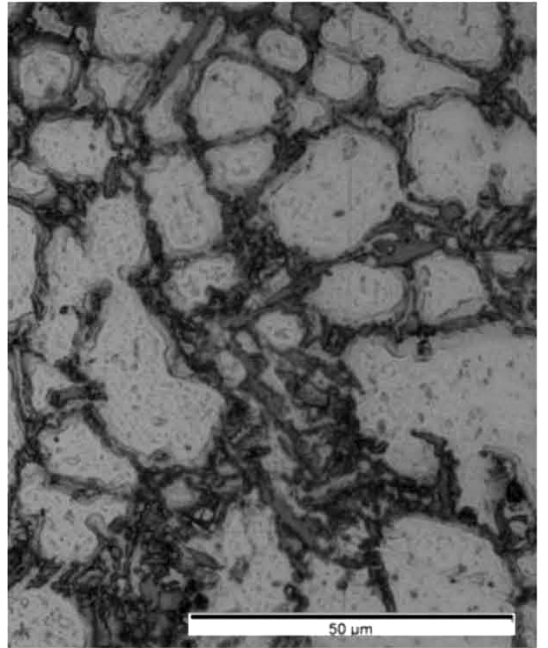

d) $\mathrm{C1}-0,1$

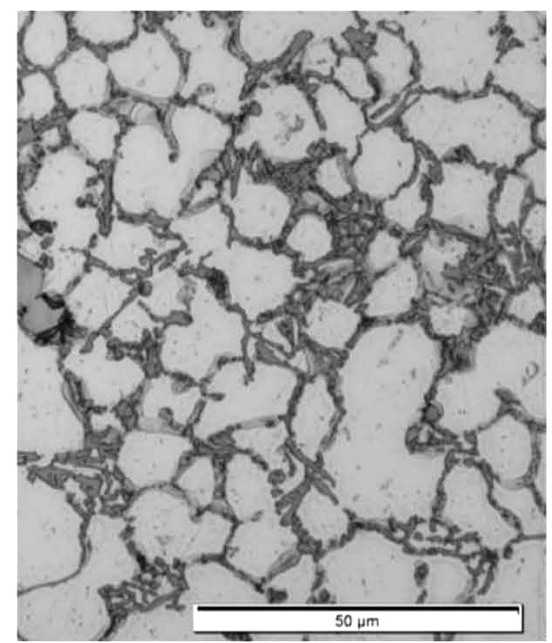

b) $\mathrm{C} 1-0,05$

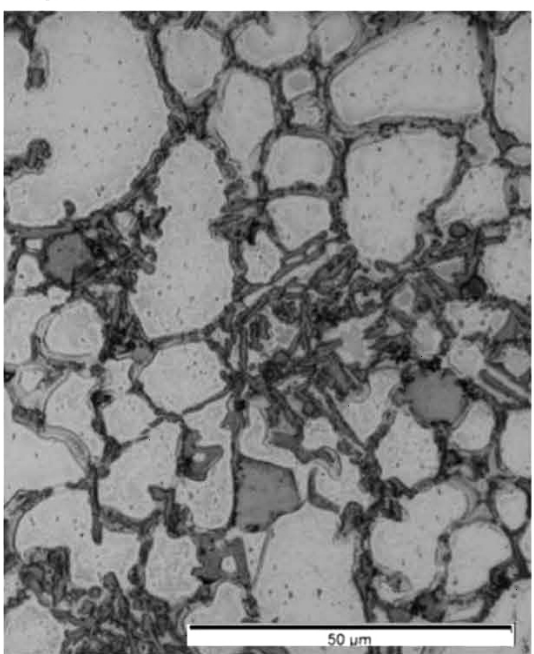

e) $\mathrm{C} 2-0,1$

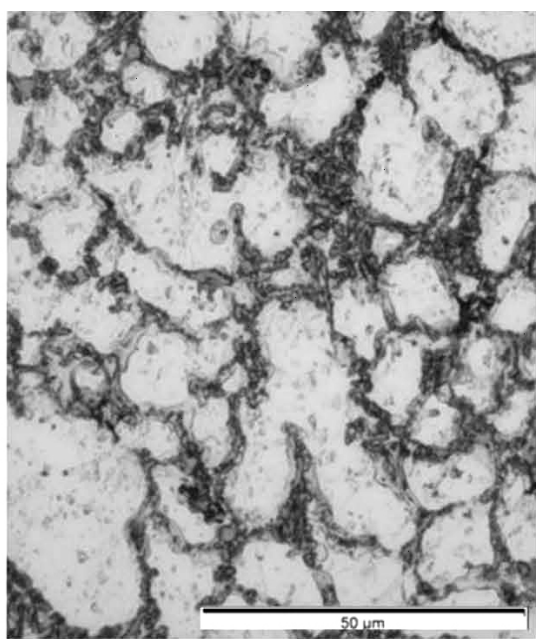

c) $\mathrm{C2}-0,05$

Figure 6: Micrographs of the a) base alloy, and b-e) nanocomposites samples

with conditions of reducing the $\mathrm{CO}_{2}$ footprint already in the parts production by developing materials that decrease the vehicle's weight and fuel consumption.

We can assume that the process of adding MWCNTs to the base alloy for HPDC needs some improvement. In an aim to overcome the agglomeration and the nonhomogenous distribution, future research will focus on finding new ways of introducing MWCNTs into the Al matrix, for example, adding MWCNTs in the pre-furnace of the HPDC machine with mechanical mixing under an inert atmosphere and the addition of alloying elements for an improvement of the interphase wetting.

\section{CONCLUSIONS}

MWCNTs were used as fillers for the preparation of nanocomposites based on an $\mathrm{AlSi} 9 \mathrm{Cu} 3(\mathrm{Fe})$ matrix (3 different MWCNT contents and 2 different positions of adding). The SEM analysis visually confirmed the thermal stability of the MWCNTs in the Al-matrix nanocomposite samples prepared by the HPDC method. Experimental testing showed increased mechanical properties, especially for nanocomposites with $0.05 \mathrm{w} / \%$ MWCNT (position 1): elongation at break by $30 \%$ and tensile strength by $4.4 \%$. The homogenous distribution of the MWCNTs for the best C1-0.05 sample was also confirmed by the low discrepancy of the mechanical results and the SEM imaging at a magnification of $30 \mathrm{k} \times$.

The finest microstructure (smaller size of $\mathrm{Al}$ primary grains) also showed samples with $0.05 w / \%$ MWCNT at position 1 (in front of the piston in the HPDC machine), which is in correlation with the largest improvement in the mechanical properties.

Altogether, the main reason for some of the observed inhomogeneous results in the nanocomposite samples can be found in the agglomeration of the MWCNTs caused by a small surface activity between the MWCNTs and the base alloy, which should be overcome, probably 


\section{V. ŠPADA et al.: INVESTIGATION OF THE MECHANICAL PROPERTIES OF AlSi9Cu3(Fe)/MWCNT NANOCOMPOSITES ...}

by active alloying elements and mixing under an inert atmosphere.

\section{REFERENCES}

${ }^{1}$ L. Jiaoyan, J. D. Lee, K. P. Chong, Multiscale analysis of composite material reinforced by randomly-dispersed particles, International Journal of Smart and Nano Materials, 3 (2012) 1, 2-13, doi:10.1080/ 19475411.2011.637995

${ }^{2}$ M. T. Byrne, J. E. McCarthy, M. Ben, R. Blake, Y. K. Gun'ko, E. Horvath, Z. Konya, A. Kukovecz, I. Kiricsi, J. N. Coleman, Chemical functionalization of titanium nanotubes and their utilization for the fabrication of reinforced polystyrene composites, Journal of Materials Chemistry, 17 (2007), 2351-2358, doi:10.1039/b612886f

${ }^{3}$ H.-J. Song, Z.-Z. Zhang, X.-H. Men, Tribological behaviour of polyurethane-based composite coating reinforced with $\mathrm{TiO} 2$ nanotubes, European Polymer Journal, 44 (2008), 1012-1022, doi:10.1016/ j.progpolymsci.2006.05.003

${ }^{4}$ I. Brnardić, M. Huskić, P. Umek, A. Fina, T. Holjevac Grgurić, Synthesis of silane functionalized sodium titanate nanotubes and their influence on thermal and mechanical properties of the epoxy nanocomposite, Physica Status Solidi, A 210 (2013), 2284-2291, doi:10.1002/pssa.201329281

${ }^{5}$ L. Valentini, J. Macan, I. Armentano, F. Mengoni, J. M. Kenny, Modification of fluorinated single-walled carbon nanotubes with amino-silane molecules, Carbon, 44 (2006), 2196-2201, doi:10.1016/j.carbon.2006.03.007

${ }^{6}$ Q. Li, C. A. Rottmair, R. F. Singer, CNT reinforced light metal composites produced by melt stirring and by high pressure die casting, Composites Science and Technology, 70 (2010), 2242-2247, doi:10.1016/j.compscitech.2010.05.024

${ }^{7}$ H. Uozumi, K. Kobayashi, K. Nakanishi, T. Matsunaga, K. Shinozaki, H. Sakamoto, T. Tsukada, C. Masuda, M. Yoshida, Fabrication process of carbon nanotube/light metal matrix composites by squeeze casting, Materials Science and Engineering, A 495 (2008), 282-287, doi:10.1016/j.msea.2007.11.088

${ }^{8}$ T. Laha, Y. Liu, A. Agarwal, Carbon nanotube reinforced aluminum nanocomposite via plasma and high-velocity oxy-fuel spray forming, Journal of Nanoscience and Nanotechnology, 7 (2007), 1-10, doi:10.1016/j.surfcoat.2008.05.042

${ }^{9}$ X. N. Hao, H. P. Zhang, R. X. Zheng, Y. T. Zhang, K. Ameyama, C. L. Ma, Effect of mechanical alloying time and rotation speed on the evolution of CNTs/Al-2024 composite powders, Trans. Nonferrous Met. Soc. China, 24 (2014), 2380-2386, doi:10.1016/S10036326(14)63360-4

${ }^{10}$ S. Sankara Narayanan, G. Manickavasaham, S. Moorthy, Experimental investigation of aluminium alloy with MWCNT composite to increase the mechanical properties by stir casting method, IOSR Journal of Mechanical and Civil Engineering (IOSR-JMCE), 124 II (2015), 30-34, doi:10.9790/1684-12423034

${ }^{11}$ A. Powell, The fabrication of aluminium-carbon nanotube metal matrix composites, School of Metallurgy and Materials, University of Birmingham, 2013, doi:10.1016/j.rinp.2016.04.013

${ }^{12}$ X. Zeng, G. H. Zhou, Q. Xu, Y. Xiong, C. Luo, J. Wu, A new technique for dispersion of carbon nanotube in the metal melt, Materials Science and Engineering, A527 (2010), 5335-5340, doi:10.1016/ j.jart.2016.05.002

${ }^{13}$ S. R. Bakshi, D. Lahiri, A. Agarwal, Carbon nanotube reinforced metal matrix composites - a review, International Materials Reviews, 55 (2010) 1, doi:10.1179 /095066009X12572530170543

${ }^{14}$ R. Casati, M. Vedani, Metal matrix composites reinforced by nano-particles - a review, Metals, 2075-4701 (2014) 4, 65-83, doi:10.3390/met4010065
${ }^{15}$ T. Noguchi, A. Magario, S. Fukazawa, S. Shimizu, J. Beppu, M. Seki, Carbon Nanotube/Aluminium Composites with Uniform Dispersion, Materials Transactions, The Japan Institute of Metals, 45 (2004) 2, 602-604, doi:10.2320/matertrans.45.602

${ }^{16}$ S. C. Tjong, Novel nanoparticle- reinforced metal matrix composites with enhanced mechanical properties, Advanced Engineering Materials, 9(8) (2007), 639-652, doi:10.1002/adem.200700106

${ }^{17}$ J. Stein, B. Lenczowski, N. Fréty, E. Anglaret, High-performance metal matrix composites reinforced by carbon nanotubes, 18th International conference on composite materials, (2011), doi:10.1016/ j.compscitech.2010.05.004, 2010

${ }^{18}$ A. B. Elshalakany, T. A. Osman, A. Khattab, B. Azzam, M. Zaki, Microstructure and mechanical properties of MWCNTs reinforced A356 aluminum alloys cast nanocomposites fabricated by using a combination of rheocasting and squeeze casting techniques, Journal of Nanomaterials, B (2014), 386370, doi:10.1155/2014/ 386370

${ }^{19}$ R. Shadakshari, K. Dr. Mahesha, H. B. Dr. Niranjan, Carbon nanotube reinforced aluminium matrix composites-a review, International Journal of Innovative Research in Science, Engineering and Technology, 12 (2012), 206, doi:10.1179/ 095066009X12572530170543

${ }^{20}$ A. K. Srivastava, C. L. Xu, B. Q. Wei, R. Kishore, K. N. Sood, Microstructural features and mechanical properties of carbon nanotubes reinforced aluminium-based metal matrix composites, Indian Journal of Engineering and Material Sciences, 15 (2008), 247-255, doi:10.1002/1527-2648(200106)3:6<357::AID-ADEM357>3.0.CO;2 $-\mathrm{I}$

${ }^{21} \mathrm{~S}$. Chatterjee, A. B. Mallick, Challenges in manufacturing aluminium based metal matrix nanocomposites via stir casting route, Material Science Forum, 736 (2013), 72-80, doi:10.4028/www.scientific.net/ MSF.736.72

${ }^{22}$ J. Hashim, L. Looney, M. S. J. Hasmi, The wettability of SiC particles by molten aluminium alloy, Journal of Materials Processing Technology, $119 \quad$ (2001), 324-328, doi:10.1016/S09240136(01)00975-X

${ }^{23}$ F. Khodabakhshi, A. P. Gerlich, P. Švec, Reactive friction-stir processing of an Al-Mg alloy with introducing multi-walled carbon nano-tubes (MW-CNTs), Microstructural characteristics and mechanical properties, Materials Characterization (2017), doi:10.1016/j.matchar.2017.07.027

${ }^{24}$ J. Prasek, J. Drbohlavova, J. Chomoucka, J. Hubalek, O. Jasek, V. Adamc, R. Kizek, Methods for carbon nanotubes synthesis-review, J. Mater. Chem., 21 (2011), 15872, doi:10.1039/C1JM12254A

${ }^{25} \mathrm{~J}$. Yang, Carbon nanotubes as reinforcements and interface modifiers in metal matrix composites, These N3140, La Faculte Sciences de Base, Lausanne (2004), doi:10.1163/156855497X00046

${ }^{26}$ A. Mahajan, A. Kingon, A. Kukovecz, Z. Konya, P. M. Vilarinho, Studies on the thermal decomposition of multiwall carbon nanotubes under different atmospheres, Materials Letters 90 (2013), 165-168, doi:10.1016/j.matlet.2012.08.120

${ }^{27}$ E. W. Wong, P. E. Sheehan, C. M. Lieber, Nanobeam mechanics, elasticity, strength, and toughness of nanorods and nanotubes, Science 277 (1997), 1971, doi:10.1126/science.277.5334.1971

${ }^{28}$ J. P. Salvetat, A. J. Kulik, J. M. Bornard, G. A. D. Briggs, T. Stöckli, K. Méténier, S. Bonnamy, F. Béguin, N. A. Burnham, L. Forró, Elastic modulus of ordered and disordered multiwalled carbon nanotubes, Adv. Mater 112 (1999), 161, doi:10.1002/(SICI)15214095(199902)11:2<161::AID-ADMA161>3.0

${ }^{29}$ DIN EN 1706:2013, Aluminium and aluminium alloys - castings, chemical composition, and mechanical properties, European Committee for Standardization, Brussels 